American Journal of Environmental Sciences 5 (3): 295-302, 2009

ISSN 1553-345X

(C) 2009 Science Publications

\title{
Mountain Sheep: An Environmental Epidemiological Survey of Variation in Metal Exposure and Physiological Biomarkers Following Mine Development
}

\author{
${ }^{1}$ Lawrence K. Duffy, ${ }^{2}$ Michael W. Oehler, Sr., ${ }^{3}$ R. Terry Bowyer and ${ }^{3}$ Vernon C. Bleich \\ ${ }^{1}$ Department of Chemistry and Biochemistry, University of Alaska Fairbanks, \\ P.O. Box 756160, Fairbanks, AK 99775-6160, USA \\ ${ }^{2}$ Theodore Roosevelt National Park, National Park Service, 315 2nd Avenue, \\ Medora, ND 58645, USA \\ ${ }^{3}$ Department of Biological Sciences, 921 South 8th Avenue, Stop 8007, \\ Idaho State University, Pocatello, ID 83209-8007, USA
}

\begin{abstract}
Problem Statement: Anthropogenic activities, such as mining and industrial operations, are a major environmental source of metal exposure for wildlife. Quantitative data regarding biochemical effects of exposure to mineral extraction on mountain sheep, Ovis canadensis, are limited, although their habitats are becoming increasingly affected by expanded resource development. Decisions relating to environmental protection and wildlife conservation should be based on sound scientific understanding of the interaction of released metals with the biota. Approach: Because understanding of the biogeochemistry, food webs, and metals as stressors was limited for arid environments, scientists and managers need to take a monitoring approach that incorporates a longer time scale using resembling designs. We tested the hypothesis that mountain sheep exposed to mining activities would express elevated levels of biomarkers compared with a reference group that was not directly exposed to mining activities. During this study, conducted in the Mojave Desert of California, USA, from 1995-1997, we analyzed concentrations of selected metals in blood of mountain sheep as biomarkers of exposure using a simultaneous treatment-reference design. We included common physiological biomarkers of effect, such as haptoglobin and interleukin-6. These variables were measured in two subpopulations of female mountain sheep inhabiting distinct geographic areas (mined and non-mined) within a single mountain range over 2 years. Results: Although the sample size was small, metal exposure was significantly higher in mountain sheep inhabiting the mined area. Plasma protein levels in these sheep inhabiting the mined area were also significantly higher than for mountain sheep in the non-mined area. Conclusion: Local biomonitoring studies during mining and other developments were important sources of baseline information about the health of wildlife populations, which allowed managers to establish benchmarks related to exposure.
\end{abstract}

Key words: Mountain sheep, Ovis canadensis, mining, Mojave desert, metals, biomarkers, haptoglobin, interleukin

\section{INTRODUCTION}

Civilization relies heavily on the mining industry to produce the raw materials necessary for improving the human condition. The mining industry may need to expand continuously to meet the demands of increasing economic growth ${ }^{[1]}$. Nevertheless, mining operations may alter pristine or cultivated areas by generating large amounts of solid or liquid byproducts. Mining wastes, which can cover large areas, include overburdens and tailings, and have resulted in degraded lands including tailing dams ${ }^{[2,3]}$. Indirect effects of mineral extraction can include soil erosion, water pollution and toxicity ${ }^{[2]}$, potentially resulting in a loss of biodiversity. Biomonitoring of elements is important to assess and regulate ecosystem health in landscapes influenced by mining activity ${ }^{[4,5]}$, especially during restoration ${ }^{[6]}$. Plants can absorb trace elements from the soil, water, or air and retain them for years. These trace elements can enter the food web via animals feeding on leaves, roots, bark and fruits ${ }^{[7-10,32,37,38]}$.

Metal and protein levels in blood are useful measures in evaluating the physical condition of ruminants and other mammals ${ }^{[11-17,24,34-36]}$. Once an

Correspondence Author: Lawrence K. Duffy, Department of Chemistry and Biochemistry, University of Alaska Fairbanks, P.O. Box 756160, Fairbanks, AK 99775-6160, USA Tel: 907-474-7525 Fax: 907-474-5101 
animal is in hand, these biomarkers are: (1) easy to obtain; (2) can be monitored repetitively; and (3) do not require destruction of animals. Quantitative studies regarding biochemical effects of exposure to mineral extraction on mountain sheep, Ovis canadensis, are rare. Nonetheless, the habitats of mountain sheep are increasingly affected by resource development ${ }^{[18-20]}$. Decisions relating to environmental protection and wildlife conservation should be based on sound scientific understanding of the interaction of released metals with the biota ${ }^{[20-22]}$. Because our understanding of biogeochemistry, food webs, and metals as stressors is limited for arid environments, scientists and managers must use monitoring approaches that incorporate extended periods of time and repeated sampling of animals.

The aims of this survey were: (1) to monitor the concentration of 12 trace elements $(\mathrm{Ag}, \mathrm{As}, \mathrm{Cd}, \mathrm{Cr}, \mathrm{Cu}$, $\mathrm{Fe}, \mathrm{Hg}, \mathrm{Mn}, \mathrm{Ni}, \mathrm{Pb}, \mathrm{Se}, \mathrm{Zn}$ ) in the blood of wild mountain sheep over a 2-year period (June 1995January 1997); (2) to evaluate the potential health effects by analyzing biomarkers in the blood; and (3) compare blood metal levels to toxic thresholds. We hypothesized that mountain sheep exposed to mining activities would exhibit blood biomarkers that were elevated when compared with the reference group.

\section{MATERIALS AND METHODS}

Study area and animals: In December 1995, Canyon Resources Corporation began construction of an openpit, heap-leach gold mine (hereafter the Briggs Mine) located in the Mojave Desert, Inyo County, California, USA. Excavation, crushing, and on-site processing of ore began in March, July and October 1996, respectively. The Briggs Mine was projected to process $\sim 19.3$ million metric tons of ore on site during the 7year life of the mine and to disturb 1,333 ha of land within the 2,350-ha project area. Our study was conducted on the west-facing slope of the Panamint Range; the subpopulation of female mountain sheep living near the mine was centered on Redlands Spring (36 $\left.56^{\prime} 37^{\prime \prime} \mathrm{N}, 117^{\circ} 10^{\prime} 43^{\prime \prime} \mathrm{W}\right)$ in the southern end of our study area, whereas the center of our reference population (i.e., non-mined) was located $\sim 22 \mathrm{~km}$ to the north (36 $\left.09^{\prime} 34^{\prime \prime} \mathrm{N}, 117^{\circ} 09^{\prime} 50^{\prime \prime} \mathrm{W}\right)$.

Elevations range from $305 \mathrm{~m}$ on the valley floor to $3,368 \mathrm{~m}$ at Telescope Peak. Mean $( \pm \mathrm{SE})$ annual rainfall from 1911-1994 at the weather station $\sim 30 \mathrm{~km}$ from our study site (Greenland Range-Furnace Creek, California) was $4.7 \pm 0.33 \mathrm{~cm}$. Temperature was highly variable, with daytime highs ranging from $40^{\circ} \mathrm{C}$ during summer
(May-August), to $-7^{\circ} \mathrm{C}$ during spring (January-April). Mountain sheep were at relatively low densities (72 adult females/1,000 $\mathrm{km}^{2}$ ) in the Panamint Range $^{[18,19]}$.

Adult female mountain sheep ( $\geq 1$-year-of-age) were captured during June and October 1995, June 1996 and January 1997 with a helicopter and net-gun as detailed by Oehler et al. ${ }^{[18]}$. All aspects of animal handling complied with protocols set forth by the California Department of Fish and Game and were consistent with methods adopted by the Ad Hoc Committee of the American Society of Mammalogists on Acceptable Field Methods.

Biochemical analysis: Haptoglobin (Hp) in blood samples of mountain sheep was quantified by electrophoresis as Hp-hemoglobin complexes. Hemoglobin $(\mathrm{Hb})$ was added to the serum (1-20 ratio of hemoglobin $[10 \%$ solution] to serum sample. The sample mixture was then separated on agarose gels at $100 \mathrm{~V}$ for $1 \mathrm{~h}$ and the protein complex then was fixed with $7.5 \%$ trichloroacetic acid. Gels were stained for $\mathrm{Hb}$ using o-dianisidine (Helena Laboratories, Beaumont, TX; Tech. Bull. No. 5445). The Hp-Hb complex, which migrates in a different region from $\mathrm{Hb}$, was quantitated by densitometry; results were expressed as milligrams of hemoglobin-binding capacity over $100 \mathrm{~mL}$ serum. The accuracy of Hp quantification is based on the specificity of the Hp-Hb complex formation, which is separated by electrophoresis. The reproducibility of the $\mathrm{Hp}$ assay from comparison samples in previous $\mathrm{Hp}$ assays of river otters (Lontra canadensis) was indicated by interassay CV of $14.8 \%$. This CV is similar to those reported in analyses of Hp levels for dogs and other species ${ }^{[13,24,32]}$.

Interleukin (IL-6 ir) was determined by ELISA assay ${ }^{[24]}$. The interassay percentage of variation for the interleukin assay as described by R. and D. Systems (Minneapolis, MN) was 7.1\% at the $90-p g \mathrm{~mL}^{-1}$ level. Samples examined in duplicate were added to a microtiter plate coated with a monoclonal antibody for IL-6. After washing away any unbound proteins, an enzyme-linked polyclonal antibody for IL- 6 was added to the wells and incubated to allow for binding any IL-6 in the wells. After a final wash, a substrate solution was added to the wells and color developed; concentrations were determined from a standard curve. Enzyme concentrations were determined with standard clinical auto analyzer procedures at Northern Inyo Hospital, Bishop, California. In all instances, a single analysis was performed, except for IL-6, which was described previously. 
Am. J. Environ. Sci., 5 (3): 295-302, 2009

Trace elements: Blood samples were stored at $-70^{\circ} \mathrm{C}$ until analyzed. Trace metals were analyzed with atomic absorbance spectroscopy with the standard method for blood samples used for biomonitoring ${ }^{[39]}$. The instrument was calibrated with matrix-matched standards.

Statistical analysis: Multivariate analysis of variance (MANOVA) was employed and all individual factor levels and their interactions were evaluated; significant models $(p \leq 0.05)$ were explored further with Tukey's Honestly Significant Difference (HSD). We analyzed data using the software PC SAS (SAS Institute Inc. 1997). We used the Bonferroni correction when conducting multiple comparisons. We examined assumptions of each statistical test and transformed data as necessary to meet those assumptions. Bivariate correlations were evaluated with a Pearson productmoment correlation ${ }^{[26]}$. An $\alpha=0.05$ was adopted for all tests.

\section{RESULTS}

We evaluated levels of metals in blood for each mountain sheep, including concentrations on recapture of individuals (Table 1 and 2). Metal levels in blood generally reflect recent exposure rather than accumulated body burden. In general, metal levels in plasma of sheep in the mined area were higher than those inhabiting the non-mined reference site. Eight sheep from the non-mined reference area and 10 sheep from the mined area all possessed levels for mercury $(\mathrm{Hg})$ below $0.5 \mu \mathrm{g} \mathrm{L}^{-1}$. Cadmium $(\mathrm{Cd})$ also was below criteria for concern, with the highest level measured at $0.042 \mu \mathrm{g} \mathrm{L}^{-1}$ and exhibiting low levels in both the mined and non-mined site. $\mathrm{Cu}, \mathrm{Zn}$ and $\mathrm{Fe}$ occurred at higher concentrations (means: $\mathrm{Cu}, 10.10 ; \mathrm{Fe}, 7.52$ and $\mathrm{Zn}, 21.8 \mu \mathrm{g} \mathrm{L}^{-1}$ ), but also below toxic levels. Selenium (Se) was the most variable and, in general, showed a declining pattern over time in the non-mined reference area (mean $18.4 \mu \mathrm{g} \mathrm{L}^{-1}$ ). The higher metal exposure to mountain sheep in the mined area was significant $(p=0.040)$ despite the variation in the level of metals from sheep in the reference area.

We also investigated biomarkers of effect associated with the acute-phase response and activation of the immune system (Table 3 and 4). For individual mountain sheep, Hp and IL-6 were not related to either the mined or non-mined areas. For IL- 6,6 detections (30\%) and 4 detections (23\%) were observed in sheep occupying the mined and reference subpopulations, respectively. The reverse was observed for the acutephase protein Hp (2 detections [10\%] in the mined area vs. 4 detections [23\%] in the reference area (Table 3 and 4).
Table 1: Concentrations of selected metals in female mountain sheep in Panamint Range, Inyo County, CA, USA, from 1995-1997

\begin{tabular}{|c|c|c|c|c|c|c|c|c|}
\hline \multirow{3}{*}{$\begin{array}{l}\text { Sheep } \\
\text { ID } \\
\text { No. }\end{array}$} & \multirow{3}{*}{$\begin{array}{l}\text { Age } \\
\text { (Years) }\end{array}$} & \multicolumn{2}{|c|}{ Sample date } & \multirow[b]{3}{*}{$\mathrm{Cd}$} & \multirow[b]{3}{*}{$\mathrm{Cu}$} & \multirow[b]{3}{*}{$\mathrm{Fe}$} & \multirow[b]{3}{*}{$\mathrm{Se}$} & \multirow[b]{3}{*}{$\mathrm{Zn}$} \\
\hline & & & ---- & & & & & \\
\hline & & $\mathrm{Y}$ & M & & & & & \\
\hline \multicolumn{9}{|c|}{ Non-mined reference area } \\
\hline \multirow[t]{2}{*}{25} & 2 & 95 & 06 & 0.015 & 9.61 & 5.67 & 8.36 & 17.2 \\
\hline & 2 & 95 & 10 & 0.001 & 7.94 & 3.96 & 0.24 & 22.4 \\
\hline \multirow[t]{3}{*}{83} & 4 & 95 & 06 & 0.023 & 8.94 & 7.56 & 11.76 & 26.4 \\
\hline & 4 & 95 & 10 & 0.032 & 8.07 & 4.64 & 0.05 & 21.1 \\
\hline & 6 & 97 & 10 & 0.001 & 6.59 & 4.95 & 6.67 & 20.3 \\
\hline \multirow[t]{2}{*}{162} & 5 & 95 & 06 & 0.027 & 12.03 & 19.65 & 2.47 & 20.0 \\
\hline & 5 & 95 & 10 & 0.025 & 9.13 & 9.75 & 0.56 & 30.3 \\
\hline 190 & 3 & 95 & 10 & 0.001 & 8.75 & 5.78 & 0.66 & 24.4 \\
\hline \multirow[t]{2}{*}{285} & 5 & 95 & 06 & 0.009 & 14.59 & 4.71 & 9.42 & 18.2 \\
\hline & 5 & 95 & 10 & 0.001 & 9.32 & 5.72 & 0.50 & 19.2 \\
\hline 325 & 5 & 95 & 10 & 0.029 & 8.88 & 5.40 & 1.60 & 18.4 \\
\hline \multirow[t]{2}{*}{335} & 5 & 95 & 06 & 0.030 & 9.47 & 3.85 & 1.56 & 17.8 \\
\hline & 6 & 96 & 06 & 0.001 & 13.31 & 4.64 & 1.07 & 13.4 \\
\hline \multirow[t]{2}{*}{525} & 2 & 95 & 06 & 0.021 & 12.11 & 4.64 & 7.76 & 21.9 \\
\hline & 4 & 97 & 10 & 0.001 & 9.17 & 7.81 & 0.01 & 23.6 \\
\hline \multirow[t]{2}{*}{642} & 6 & 95 & 10 & 0.042 & 10.25 & 4.01 & 1.32 & 14.3 \\
\hline & 8 & 97 & 10 & 0.001 & 8.41 & 13.89 & 0.42 & 19.3 \\
\hline
\end{tabular}

Units: $\mu \mathrm{g} \mathrm{L}^{-1}$; $\mathrm{Y}=$ Year; $\mathrm{M}=$ Month

Table 2: Mined area

\begin{tabular}{|c|c|c|c|c|c|c|c|c|}
\hline \multirow[b]{2}{*}{ Sheep } & \multirow[b]{2}{*}{$\begin{array}{l}\text { Age } \\
\text { (Years) }\end{array}$} & \multicolumn{2}{|c|}{ Sample date } & \multirow[b]{2}{*}{$\mathrm{Cd}$} & \multirow[b]{2}{*}{$\mathrm{Cu}$} & \multirow[b]{2}{*}{$\mathrm{Fe}$} & \multirow[b]{2}{*}{$\mathrm{Se}$} & \multirow[b]{2}{*}{$\mathrm{Zn}$} \\
\hline & & Y & $\mathrm{M}$ & & & & & \\
\hline \multirow[t]{2}{*}{8} & 6 & 96 & 06 & 0.001 & 10.82 & 8.57 & 4.91 & 25.7 \\
\hline & 7 & 97 & 10 & 0.001 & 10.00 & 19.08 & 0.01 & 34.8 \\
\hline \multirow[t]{2}{*}{70} & 5 & 96 & 06 & 0.001 & 11.62 & 5.75 & 0.12 & 20.6 \\
\hline & 6 & 97 & 10 & 0.001 & 9.72 & 2.76 & 0.01 & 22.9 \\
\hline \multirow[t]{2}{*}{102} & 1 & 95 & 10 & 0.001 & 14.59 & 1.69 & 0.15 & 13.2 \\
\hline & 3 & 97 & 10 & 0.001 & 11.04 & 4.71 & 0.02 & 27.4 \\
\hline 115 & 4 & 96 & 06 & 0.001 & 7.89 & 8.57 & 6.06 & 13.3 \\
\hline 130 & 3 & 96 & 06 & 0.006 & 15.84 & 11.66 & 0.01 & 31.7 \\
\hline \multirow[t]{2}{*}{222} & 7 & 95 & 06 & 0.104 & 10.75 & 6.45 & 5.14 & 17.0 \\
\hline & 7 & 95 & 10 & 0.001 & 19.31 & 1.68 & 0.01 & 17.1 \\
\hline \multirow[t]{3}{*}{663} & 5 & 95 & 06 & 0.011 & 10.25 & 7.84 & 5.15 & 12.1 \\
\hline & 5 & 95 & 10 & 0.001 & 14.63 & 1.71 & 0.27 & 13.4 \\
\hline & 7 & 97 & 10 & 0.001 & 10.27 & 2.78 & 0.13 & 17.8 \\
\hline \multirow[t]{3}{*}{692} & 5 & 95 & 06 & 0.001 & 9.24 & 5.72 & 0.43 & 17.1 \\
\hline & 5 & 95 & 10 & 0.008 & 7.66 & 4.62 & 0.22 & 21.2 \\
\hline & 7 & 97 & 10 & 0.001 & 8.50 & 9.71 & 0.01 & 30.2 \\
\hline \multirow[t]{2}{*}{702} & 1 & 95 & 10 & 0.001 & 7.77 & 3.6 & 0.01 & 17.6 \\
\hline & 3 & 97 & 10 & 0.001 & 8.28 & 26.75 & 0.18 & 37.0 \\
\hline \multirow[t]{2}{*}{712} & 6 & 96 & 06 & 0.001 & 10.79 & 6.72 & 5.23 & 17.6 \\
\hline & 7 & 97 & 10 & 0.001 & 9.02 & 4.66 & 1.94 & 29.0 \\
\hline
\end{tabular}

In the mined area, some biomarkers such as IL-6 declined with time (Table 3). Logistic regression indicated that total protein was the only variable that significantly differentiated sheep inhabiting mined and non-mined areas. Although little effect occurred in an individual protein such as $\mathrm{Hp}$, overall increase in plasma proteins indicates an overall effect on protein synthesis. Lastly, no interpretable pattern was observed in the blood-enzyme levels with either location or age. 
Am. J. Environ. Sci., 5 (3): 295-302, 2009

Table 3: Biomarker concentrations in female mountain sheep in Panamint Range, Inyo County, CA, USA, from October 1995 to January 1997

\begin{tabular}{|c|c|c|c|c|c|c|c|c|}
\hline \multirow[b]{2}{*}{ Sheep } & \multirow{2}{*}{$\begin{array}{l}\text { Age } \\
\text { (Years) }\end{array}$} & \multicolumn{2}{|c|}{ Sample date } & \multirow[b]{2}{*}{ Alb } & \multirow[b]{2}{*}{ Hр } & \multirow[b]{2}{*}{ Protein } & \multirow[b]{2}{*}{ IL-6 } & \multirow[b]{2}{*}{ Ure: } \\
\hline & & $\mathrm{Y}$ & M & & & & & \\
\hline \multicolumn{9}{|c|}{ Non-mined reference area } \\
\hline \multirow[t]{2}{*}{25} & 2 & 95 & 06 & 3.6 & 65.5 & 7.5 & - & 16 \\
\hline & 2 & 95 & 10 & 2.8 & 87.0 & 6.5 & - & 8 \\
\hline \multirow[t]{3}{*}{83} & 4 & 95 & 06 & 3.9 & - & 7.8 & - & 10 \\
\hline & 4 & 95 & 10 & 3.8 & - & 7.8 & 9.0 & 9 \\
\hline & 6 & 97 & 01 & 3.7 & - & 7.3 & - & 11 \\
\hline \multirow[t]{2}{*}{162} & 5 & 95 & 06 & 4.0 & - & 8.2 & 0.5 & 17 \\
\hline & 5 & 95 & 10 & 3.3 & 124.0 & 7.2 & - & 11 \\
\hline 190 & 3 & 95 & 10 & 3.6 & - & 6.9 & - & 6 \\
\hline \multirow[t]{2}{*}{285} & 5 & 95 & 06 & 3.2 & - & 8.2 & - & 9 \\
\hline & 5 & 95 & 10 & 3.4 & 112.0 & 8.1 & - & 8 \\
\hline 325 & 5 & 95 & 10 & 3.4 & - & 7.3 & - & 9 \\
\hline \multirow[t]{2}{*}{335} & 5 & 95 & 06 & 3.8 & - & 7.9 & 15.5 & 12 \\
\hline & 6 & 96 & 06 & 3.5 & - & 8.0 & - & 27 \\
\hline \multirow[t]{2}{*}{525} & 2 & 95 & 06 & 3.2 & - & 6.2 & 3.0 & 20 \\
\hline & 4 & 97 & 10 & 3.8 & - & 7.8 & - & 12 \\
\hline \multirow[t]{2}{*}{642} & 6 & 95 & 10 & 3.0 & - & 7.0 & - & 6 \\
\hline & 8 & 97 & 10 & 3.5 & - & 8.0 & - & 6 \\
\hline
\end{tabular}

Units: Alb: $\mathrm{g} \mathrm{dL}^{-1}$; Protein: $\mathrm{g} \mathrm{dL}^{-1}$; Urea: $\mathrm{mg} \mathrm{dL}^{-1} ; \mathrm{Y}=$ Year; $\mathrm{M}=$ Month

Table 4: Mined area

\begin{tabular}{|c|c|c|c|c|c|c|c|c|}
\hline \multirow[b]{2}{*}{ Sheep } & \multirow[b]{2}{*}{$\begin{array}{l}\text { Age } \\
\text { (Years) }\end{array}$} & \multicolumn{2}{|c|}{ Sample date } & \multirow[b]{2}{*}{ Alb } & \multirow[b]{2}{*}{$\mathrm{Hp}$} & \multirow[b]{2}{*}{ Protein } & \multirow[b]{2}{*}{ IL-6 } & \multirow[b]{2}{*}{$\begin{array}{l}\text { Urea } \\
\text { nitrogen }\end{array}$} \\
\hline & & $\mathrm{Y}$ & $\mathrm{M}$ & & & & & \\
\hline \multirow[t]{2}{*}{8} & 6 & 96 & 06 & 3.7 & - & 8.0 & 6.0 & 13 \\
\hline & 7 & 97 & 10 & 4.2 & - & 8.2 & - & 5 \\
\hline \multirow[t]{2}{*}{70} & 5 & 96 & 06 & 3.5 & - & 7.8 & - & 7 \\
\hline & 6 & 97 & 10 & 3.9 & - & 8.1 & - & 10 \\
\hline \multirow[t]{2}{*}{102} & 1 & 95 & 10 & 3.6 & - & 7.8 & 3.0 & 6 \\
\hline & 3 & 97 & 10 & 3.9 & - & 8.1 & - & 10 \\
\hline 115 & 4 & 96 & 06 & 3.7 & - & 8.8 & - & 8 \\
\hline 130 & 3 & 96 & 06 & 3.9 & - & 9.2 & 3.0 & 12 \\
\hline \multirow[t]{2}{*}{222} & 7 & 95 & 06 & 3.2 & - & 8.3 & - & 5 \\
\hline & 7 & 95 & 10 & 2.8 & - & 9.6 & - & 9 \\
\hline \multirow[t]{3}{*}{663} & 5 & 95 & 06 & 3.3 & - & 7.2 & - & 7 \\
\hline & 5 & 95 & 10 & 3.3 & 231.5 & 7.3 & - & 11 \\
\hline & 7 & 97 & 10 & 3.0 & - & 8.1 & - & 11 \\
\hline \multirow[t]{3}{*}{692} & 5 & 95 & 06 & 3.5 & - & 7.5 & - & 9 \\
\hline & 5 & 95 & 10 & 3.9 & - & 8.1 & 6.0 & 5 \\
\hline & 7 & 97 & 10 & 4.2 & 43.5 & 8.5 & - & 8 \\
\hline \multirow[t]{2}{*}{702} & 1 & 95 & 10 & 4.4 & - & 8.7 & 4.0 & 8 \\
\hline & 3 & 97 & 10 & 4.1 & - & 8.0 & 0.2 & 5 \\
\hline \multirow[t]{2}{*}{712} & 6 & 96 & 06 & 4.2 & - & 8.6 & - & 17 \\
\hline & 7 & 97 & 10 & 3.7 & - & 7.6 & - & 13 \\
\hline
\end{tabular}

\section{DISCUSSION}

Minerals are necessary components of proper mammalian nutrition, but metals are also toxic at high concentrations $^{[28,34]}$. Bones are composed mainly of $\mathrm{Ca}$ and $\mathrm{P}$. Fe is a component of blood, whereas $\mathrm{Zn}, \mathrm{Cu}$,
$\mathrm{Mg}, \mathrm{Mn}$ and Se are structural components of specific enzyme systems ${ }^{[33,34]}$. The excess or deficient intake of essential metals can affect the health of the animal. In some instances, metals such as $\mathrm{Cr}$ are trace micronutrients for wildlife and fish. $\mathrm{Pb}, \mathrm{Cd}$ and $\mathrm{Hg}$ are non-essential elements for nutrition and their presence at low concentrations can have adverse health effects $^{[29]} . \mathrm{Pb}$ and $\mathrm{Cd}$ can interact and interfere with the metabolism of $\mathrm{Zn}, \mathrm{Fe}, \mathrm{Cu}$ and $\mathrm{Se}^{[34]}$. Although metals such as $\mathrm{Hg}$ can enter wildlife through either inhalation or ingestion ${ }^{[33]}$, the major route of intake is through ingestion $^{[30,34,35]}$.

Metal concentrations and clinical-chemistry parameters are important as biomarkers in evaluating animal health, because these metrics index the condition of organs and identify pathology and immune function related to environmental stressors, including contaminants. Results from a previous study of foraging behavior and diet quality indicated that the female mountain sheep in the mined area were affected by activities associated with the mine ${ }^{[19]}$. For our study, MANOVA indicated that the hypothesis of a higher metal exposure of mountain sheep in the mined area than sheep in the reference site was supported. The significant difference in total protein in the blood of animals at the different sites (Table 3 and 4) is consistent with our hypothesis, that blood biomarkers would indicate effects of metal exposure. Metals bind to blood and cellular proteins, inactivating or inhibiting their function-all of which can stress the liver. The increase in blood-protein levels, although non-specific with respect to a particular mechanism, can serve as good biomarker for initial effects of mining activity on mountain sheep.

The observed pattern of a decrease in metals in blood over time (Table 1) indicates that early mining activity had the greater effect on mountain sheep and may be consistent with observed changes in activity patterns ${ }^{[18,19]}$. The increase in IL-6 also would indicate increased inflammation and stress on the immune system. Different cytokines have overlapping activities and can stimulate the liver and blood cells. In our study, mountain sheep did not, however, express both IL-6 and Hp simultaneously during our sampling, indicating that in future studies blood albumin, which tended to increase in sheep in the mined area, should be monitored too (Table 4).

ASAT, ALAT, AP, and CK normally occur inside cells but, because of cellular leakage, appear in low amounts in the blood. This leakage is increased during cell damage and necrosis. Measured enzyme activity in the blood provides a sensitive indicator of disease or other stressors. The enzymes GGT and ALAT 
traditionally are used to monitor liver disease, whereas elevated CK indicates damage to skeletal muscle and the central nervous system. Metal ingested in food or while grooming could lead to tissue inflammation. Increases in CK as well as increased detections of IL-6 levels could indicate that the liver and immune system were affected during early exposure to mining activities (Table 5 and 6). Elevations in ALAT have been reported in mammals exposed to hydrocarbons and organic chlorines ${ }^{[24,36]}$ and these changes have indicated a lessening of the integrity of hepatocytes ${ }^{[36]}$. River otters (Lontra canadensis) also have shown changes in blood enzymes upon exposure to contaminants ${ }^{[24]}$.

Table 5:Enzyme concentrations in female mountain sheep in Panamint Range, Inyo County, CA, USA, from October 1995 to January 1997

\begin{tabular}{|c|c|c|c|c|c|c|c|}
\hline \multirow[b]{2}{*}{ Sheep } & \multirow{2}{*}{$\begin{array}{l}\text { Age } \\
\text { (Years) }\end{array}$} & \multicolumn{2}{|c|}{ Sample date } & \multirow[b]{2}{*}{ CK } & \multirow[b]{2}{*}{ ALAT } & \multirow[b]{2}{*}{ GGT } & \multirow[b]{2}{*}{$\mathrm{AP}$} \\
\hline & & Y & M & & & & \\
\hline \multicolumn{8}{|c|}{ Non-mined reference area, International Units (IU) } \\
\hline \multirow[t]{2}{*}{25} & 2 & 95 & 06 & 633 & 47 & 62 & 210 \\
\hline & 2 & 95 & 10 & 342 & 40 & 86 & 120 \\
\hline \multirow[t]{3}{*}{83} & 4 & 95 & 06 & 309 & 29 & 57 & 152 \\
\hline & 4 & 95 & 10 & 431 & 35 & 72 & 90 \\
\hline & 6 & 97 & 01 & 728 & 29 & 49 & 106 \\
\hline \multirow[t]{2}{*}{162} & 5 & 95 & 06 & 137 & 42 & 134 & 204 \\
\hline & 5 & 95 & 10 & 898 & 36 & 87 & 114 \\
\hline 190 & 3 & 95 & 10 & 720 & 32 & 75 & 364 \\
\hline \multirow[t]{2}{*}{285} & 5 & 95 & 06 & 972 & 43 & 74 & 96 \\
\hline & 5 & 95 & 10 & 141 & 40 & 93 & 104 \\
\hline 325 & 5 & 95 & 10 & 1507 & 35 & 116 & 175 \\
\hline \multirow[t]{2}{*}{335} & 5 & 95 & 06 & 371 & 34 & 92 & 139 \\
\hline & 6 & 96 & 06 & 3447 & 53 & 118 & 184 \\
\hline \multirow[t]{2}{*}{525} & 2 & 95 & 06 & 146 & 46 & 92 & 253 \\
\hline & 4 & 97 & 10 & 155 & 48 & 119 & 188 \\
\hline \multirow[t]{2}{*}{642} & 6 & 95 & 10 & 274 & 34 & 61 & 109 \\
\hline & 8 & 97 & 10 & 475 & 41 & 127 & 199 \\
\hline
\end{tabular}

Table 6: Mined area

\begin{tabular}{|c|c|c|c|c|c|c|c|}
\hline \multirow[b]{2}{*}{ Sheep } & \multirow{2}{*}{$\begin{array}{l}\text { Age } \\
\text { (Years) }\end{array}$} & \multicolumn{2}{|c|}{ Sample date } & \multirow[b]{2}{*}{ CK } & \multirow[b]{2}{*}{ ALAT } & \multirow[b]{2}{*}{ GGT } & \multirow[b]{2}{*}{ AP } \\
\hline & & Y & M & & & & \\
\hline \multirow[t]{2}{*}{8} & 6 & 96 & 06 & 606 & 52 & 63 & 156 \\
\hline & 7 & 97 & 10 & 245 & 53 & 73 & 92 \\
\hline \multirow[t]{2}{*}{70} & 5 & 96 & 06 & 506 & 33 & 134 & 367 \\
\hline & 6 & 97 & 10 & 202 & 41 & 100 & 192 \\
\hline \multirow[t]{2}{*}{102} & 1 & 95 & 10 & 214 & 24 & 85 & 17 \\
\hline & 3 & 97 & 10 & 263 & 37 & 61 & 296 \\
\hline 115 & 4 & 96 & 06 & 303 & 47 & 103 & 184 \\
\hline 130 & 3 & 96 & 06 & 285 & 44 & 684 & 632 \\
\hline \multirow[t]{2}{*}{222} & 7 & 95 & 06 & 223 & 29 & 68 & 84 \\
\hline & 7 & 95 & 10 & 68 & 22 & 64 & 60 \\
\hline \multirow[t]{2}{*}{663} & 5 & 95 & 06 & 203 & 54 & 66 & 63 \\
\hline & 5 & 95 & 10 & 884 & 55 & 111 & 57 \\
\hline \multirow[t]{3}{*}{692} & 5 & 95 & 06 & 387 & 49 & 80 & 178 \\
\hline & 5 & 95 & 10 & 179 & 35 & 74 & 114 \\
\hline & 7 & 97 & 10 & 172 & 50 & 71 & 331 \\
\hline \multirow[t]{2}{*}{702} & 1 & 95 & 10 & 80 & 46 & 72 & 188 \\
\hline & 3 & 97 & 10 & 307 & 49 & 74 & 121 \\
\hline \multirow[t]{2}{*}{712} & 6 & 96 & 06 & 154 & 40 & 72 & 352 \\
\hline & 7 & 97 & 10 & 179 & 42 & 80 & 123 \\
\hline
\end{tabular}

Hp was detected in fewer mountain sheep in mined areas than in the non-mined area and mean values of Hp were more variable in the mined area (Table 2). Effects of exposure would be expected to diminish over time, as animals adapted or altered their behavior. Hp levels are the result of complex interactions with other environmental factors that vary seasonally. Our data indicate that $\mathrm{Hp}$ would be ineffective as a biomarker in sheep to monitor the long term effects of development.

Elevated detections (30\%) of IL-6 in mountain sheep in the mined area indicate that this parameter may be effective for identifying impaired immune systems that could predispose sheep to disease. Carefully controlled field experiments might confirm this, but fluctuations in other factors (e.g., climate, and forage) indicate that a very large stress would be needed to produce a difference in IL-6 levels of sheep from the reference area (Table 3 ).

There is a need for more biomarker data on mountain sheep so that pre- and post-exposure periods can be compared. Likewise, there is a necessity to continue monitoring levels of metals and biomarkers in blood over time in mountain sheep and other large mammals that may be adversely affected by resource development ${ }^{[2,20,28-30]}$. Local monitoring surveys, with repeated sampling, are an important source of information about the health of individuals within a population having increased exposure to metals. Plants grazed by mountain sheep also should be monitored to identify the transport process of the metals to the sheep. Mountain sheep in this survey occur at low density and we sampled most of the sheep in the two study areas $^{[18,19]}$. Behavioral changes between sheep occupying treatment and reference areas indicate a population-level response that was reflected in levels of protein and metals. Although it is difficult and expensive to conduct biomarker assessments, the knowledge gained could reduce uncertainty in interpretation of other types of data, such as mortality studies, and add a different type of evidence to assessment processes.

\section{CONCLUSION}

Local biomonitoring studies during development are important sources of baseline information about the health of wildlife populations, which allow managers to establish benchmarks related to exposure. Repeated sampling techniques improves monitoring data related to the exposures from the development of mining activities by allowing the resource manager to follow longitudinal trends in biomarkers in individual animals. The unique data set obtained this study in an arid 
environment, when used in conjunction with other data sets and behavioral studies, will be useful in future research evaluating the health of these mountain sheep. Blood protein levels and CK should be monitored along with metal concentrations in this and other populations.

\section{ACKNOWLEDGMENT}

This study was supported by the Institute of Arctic Biology at the University of Alaska Fairbanks, Department of Biological Sciences at Idaho State University, U.S. National Park Service, California Department of Fish and Game, North Dakota Game and Fish Department, Canyon Resources Corporation, the U.S. Bureau of Land Management and the San Fernando Valley Chapter of Safari Club International. We thank W. Allsup, R. Anthes, C. Baker, R. Barry, J. Bauer, S. DeJesus, T. Evans, E. Forner, B. Gonzales, S. Hager, M. Miller, B. Nuckolls, D. Oehler, L. Oehler, M. Oehler, Jr., A. Pauli, K. Pindel, D. Racine, E. Rexstad, J. Schlachter, K. Schwaegerle, J. Sedinger, C. Sexton, T. Swank, R. Teagle, D. Threloff, S. Torres and K. Whitten for their assistance. We also thank Canyon Resources Corporation for facilitating our research at the mine. This is a contribution from the California Department of Fish and Game Mountain Sheep Conservation Program and is Professional Paper 062 from the Eastern Sierra Center for Applied Population Ecology.

\section{REFERENCES}

1. Li, M.S., 2006. Ecological restoration of mineland with particular reference to the metalliferous mine wasteland in China: A review of research and practice. Sci. Total Environ., 357: 38-53. DOI: 10.1016/J.Scitotenv.2005.05.003

2. Medez, M.O. and R.M. Maier, 2008. Phytostabilization of mine tailings in arid and semi arid environments-an emerging remediation technology. Environ. Health Perspects., 116: 278-283. DOI: $10.1289 /$ ehp. 10608

3. Lee, Y. and Stuebing, 1990. Heavy metal contamination in the River Toad, Bufo juxtasper (Inger), near a copper mine in East Malaysia. Bull. Environ. Contam. Toxicol., 45: 272-279. http://md1.csa.com/partners/viewrecord.php?reque ster $=$ gs \& collection $=$ ENV \& recid $=2840174 \& q=$ Hea $\mathrm{vy}+$ metal+contamination+in+the+River+Toad $\% 2 \mathrm{C}$ + B.+juxtasper+\%28Inger\%29\%2C+near+a+copper + mine + in + East + Malaysia\&uid $=\&$ setcookie $=$ yes
4. LeBlond, J., L. Duffy, 2001. Toxicity assessment of total dissolved solids in effluent of Alaskan mines using 22-h chronic Microtox and Selenastrum capricornation assays. Sci. Total Environ., 271: 49-59.

5. Weber-Scannell, P. and L. Duffy, 2007. Effects of total dissolved solids on aquatic organisms: A literature review and recommendation for salmonid species. Am. J. Environ. Sci., 3: 1-6. http://www.scipub.org/fulltext/ajes/ajes311-6.pdf

6. Madejon, P., J. Murillo, T. Maranon, F. Cabrera and R. Lopez, 2002. Bioaccumulation of As, Cd, $\mathrm{Cu}, \mathrm{Fe}$ and $\mathrm{Pb}$ in wild grasses affected by the Aznalcollar mine spill (SW Spain). Sci. Total Environ., 290: 105-120. DOI: 10.1016/s00489697(01)01070-1

7. Cooke, J. and M. Johnson, 2002. Ecological restoration of land with particular reference to the mining of metals and industrial minerals: A review of theory and practice. Environ. Rev., 10: 41-71. http://pubs.nrc-cnrc.gc.ca/rp/rppdf/a01-014.pdf

8. Spitz, K and J Trudinger. 2009. Mining and the Environment. CRC Press, Boca Raton, ISBN: 9780-203-89543-6, pp: 891.

9. Noble, B. and J. Bronson, 2005. Integrating human health into environmental impact assessment: case studies of Canada's northern mining resource sector. Arctic, 58: 395-405. http://pubs.aina.ucalgary.ca/arctic/Arctic58-4-395.pdf

10. Birley, M., 2002. A review of trends in health impact assessment and the nature of the evidence used. J. Environ. Manage. Health, 13: 21-39. http://www.ingentaconnect.com/content/mcb/1083/ 2002/00000013/00000001/art00002

11. Sams, M., R. Lochmiller, C. Quallis, D. Leslie and M. Payton, 1996. Physiological correlates of neonatal mortality in an overpopulated herd of white-tailed deer. J. Mammal., 77: 179-190. http://md1.csa.com/partners/viewrecord.php?requester=g $\mathrm{s} \&$ collection $=\mathrm{ENV} \& \mathrm{recid}=3922768 \& \mathrm{q}=$ Physiological $+\mathrm{c}$ orrelates+of+neonatal+mortality+in+an+overpopulated+ herd+of+white-tailed+deer\&uid=\&setcookie=yes

12. Stickle, J., D. Miller and A.H. Lewandowski, 1994. Serum protein fractions of viable and nonviable neonatal ungulates. J. Zoo Wildlife Med., 25: 554-560.

13. Duffy, L., R. Bowyer, J. Testa and J. Faro, 1996. Acute phase proteins and cytokines in Alaskan mammals as markers of chronic exposure to environmental pollutants. Proceeding of the Exxon Oli Spill Symposium, Feb. 2-5, American Fisher Society Publication, Anchorage, Alaska, pp: 809-813. http://www.afsbooks.org/x54018xm.html 
14. Keech, M., T. Stephenson, R. Bowyer, V. Van Ballenbergh and J. Ver Hoef, 1998. Relationship between blood-serum variables and depth of rump fat in Alaskan moose. Alces, 34: 173-179.

15. Wolkers, H., J. Wensing and T. Schonewille, 1994. Effects of undernutrition on haematological and serum biochemical characteristics in red deer (Cervus elaphus). Can. J. Zool., 72: 1291-1296. http://rparticle.web-

p.cisti.nrc.ca/rparticle/AbstractTemplateServlet?cal yLang=eng \&journal $=$ cjz\& volume $=72 \&$ year $=0 \&$ iss ue $=7 \&$ msno $=$ z94-172

16. Franzman, A. and R. LeResche, 1978. Alaskan moose blood studies with emphasis on condition evaluation. J. Wildlife Manage., 42: 334-351. http://www.jstor.org/pss/3800270

17. Leresche, R., U. Seal, P. Karnes and A. Franzman, 1974. A review of blood chemistry of moose and other cervidae, with emphasis on nutritional assessment. Natural. Can., 101: 263-290.

18. Oehler, M., R. Bowyer and V. Bleich, 2003. Home ranges of female mountain sheep Ovis canadensis nelsoni: Effects of precipitation in a desert ecosystem. Mammalia, 67: 385-401. http://www.cababstractsplus.org/abstracts/Abstract. aspx?AcNo=20043050298

19. Oehler, M., V. Bleich, R. Bowyer and M. Nicholson, 2005. Mountain sheep and mining: Implications for conservation and management. California Fish Game, 91: 149-178.

http://www.isu.edu/bios/CV_Pub/Bowyer/CV_pdfs /124.pdf

20. Jansen, B., P. Krausman, J. Heffelfinger and J. DeVos, 2006. Bighorn sheep selection of landscape features in an active copper mine. Wildlife Soc. Bull., 34: 1121-1126.

http://www.bioone.org/DOI/abs/10.2193/0091$7648 \% 282006 \% 2934 \% 5 \mathrm{~B} 1121 \% 3 \mathrm{ABSSOLF} \% 5 \mathrm{D}$ 2.0.CO\%3B2

21. Brekken, A. and E. Steinnes, 2004. Seasonal concentrations of cadmium and zinc in native pasture plants: Consequences for grazing animals. Sci. Total Environ., 326: 181-195. DOI: 10.1016/j.scitotenv.2003.11.023

22. Benito, V., V. Devesa, O. Munoz, M. Suner, R. Mantero and R. Baos, 1999. Trace elements in blood collected from birds feeding in the area around Donana national Park affected by the toxic spill from the Aznalcollar mine. Sci. Total Environ., 242: 309-323. DOI: 10.1016/S00489697(99)00398-8
23. Bowyer, R., G. Blundell, M. Ben-David, S. Jewett, T. Dean and L. Duffy, 2003. Effects of the Exxon Valdez oil spill on river otters: Injury and recovery of a sentinel species. Wildlife Monogr., 153: 1-53. http://cat.inist.fr/?aModele $=$ afficheN\&cpsidt $=1500$ 5004

24. Krausman, P. and R. Bowyer, 2003. Mountain Sheep. In: Wild Mammals of North America: Biology, Management and Conservation, Feldhamer, G., B. Thompson and J. Chapman (Eds.). 2nd Edn., The Johns Hopkins University Press, Baltimore, Maryland, ISBN: 0801874165, pp: 1216.

25. Zar, J., 1984. Biostatistical Analysis. 2nd Edn., Prentice-Hall, Englewood Cliffs, New Jersey, ISBN: $013081542 \mathrm{X}, \mathrm{pp}: 352$.

26. Haye, S., V. Slaveykova and J. Payet, 2007. Terrestial ecotoxicity and effect factors of metals in life cycle assessment. Chemosphere, 68: 1489-1496. http://cat.inist.fr/?aModele $=$ afficheN\&cpsidt $=18834798$

27. Campbell, P., P. Chapman and B. Hale, 2006. Risk assessment of metals in the environment. Environ. Sci. Technol., 22: 102-131.

28. Mckelvey, W.,, R. Gwynn, N. Jeffery, D. Kass, L. Thorpe, R. Garg, C. Palmer and P. Parsons, 2007. Biomonitoring study of lead, cadmium and mercury in the blood of New York City adults. Environ. Health Perspect., 115: 1435-1441. http://www.ehponline.org/docs/2007/10056/abstrac t.html

29. Beyer, W., G. Heinz and A. Redmon, 1996. Environmental Contaminants in Wildlife: Interpreting Tissue Concentrations, Lewis Publishers, Boca Raton, ISBN: 156670071X, pp: 494.

30. Manahan, S., 2003. Toxicological Chemistry and Biochemistry. 3rd Edn., Lewis Publishers, Boca Raton, ISBN: 1566706181, pp: 425.

31. Dunlap, K., A. Reynolds and L. Duffy, 2006. Total antioxidant power in sled dogs supplemented with blueberries and the comparison of blood parameters associated with exercise. Comp. Biochem. Physiol. 143: 429-434. http://cat.inist.fr/?aModele $=$ afficheN\&cpsidt $=17672863$

32. Newman, M. and M. Unger, 2008. Fundamentals of Ecotoxicology. CRC Press, Boca Raton, ISBN: 1566705983, pp: 880.

33. Selinus, O., B. Alloway, J. Centerro, R. Riukelman, R. Fuge, V. Lindh and P. Smedley, 2005. Essentials of Medical Geology. Elsevier Academic Press, USA., ISBN: 0126363412, pp: 812.

34. Duffy, L., R. Hallock, G. Finstad and R. Bowyer, 2005b. Noninvasive environmental monitoring in Alaskan Reindeer. Am. J. Environ. Sci., 1: 249-253. http://www.scipub.org/fulltext/ajes/ajes14249253.pdf 
35. Lagadic, L. and Amiard, JC. 2000. Use of Biomarkers for Environmental Quality Assessment. CRC Press, ISBN: 9054107030, pp: 475.

36. Qiu, G., X. Feng, P. Li, S. Wang, G. Li and L. Shang et al., 2008. Methylmercury accumulation in rice (Oryza sativa L.) grown at abandoned mercury mines in Guizhou, China. J. Agric. Food Chem., 56: 2465-2468. DOI: 10.1021/jf073391a

37. Johansson, L., C. Xydas, N. Messios, E. Stoltz and M. Gregor, 2005. Growth and $\mathrm{Cu}$ accumulation by plants grown on $\mathrm{Cu}$ containing mine tailings in Cyprus. Appl. Geochem., 20: 101-107. DOI: 10.1016/j.apgeochem.2004.07.003
38. NRC (National Research Council). 2005. Mineral Tolerance of Animals. 2nd revised Edn., National Academies Press, Washington DC., USA., ISBN: 10: 0309096545, pp: 510. 